\title{
ETHICS OF SCIENCE AND RESPONSIBILITY OF SCIENTIST*
}

\author{
V.S. Mukhametzhanova \\ Peoples' Friendship University of Russia (RUDN University) \\ Miklukho-Maklaya Str., 6 Moscow, Russian Federation, 117198
}

\begin{abstract}
The article considers the notion of science ethics as well as the issue of responsibility of scientists in the modern society. The author discovers such key notions as the ethics of science, the ethos of science, determines the issues of professional and social responsibility of the scientists.

Rapid development of scientific and technical progress has resulted in emergence of new problems and moral situations related to ethics. Today's problem of scientists' responsibility for results of his/her activities and meaningful elaboration of scientific product is of particular interest for the society.

In this article the author separates the notion of the responsibility into two types: external and internal one. The external responsibility is implemented in relationships between science and the society; it is therefore commonly referred to as social one, while the internal one is represented as scientist's professional responsibility within scientific community. As the author says, the problem of the responsibility of the scientists is closely linked to issues of personal freedom and moral choice. The article establishes basic standards of professional ethics of the scientist, such as prohibition of plagiarism, distortion of the results of scientific research, unselfish search and defense of truth, the problem of freedom of scientific research and social responsibility of the researcher etc.

The problem of moral assessment of scientist's cognitive activities themselves, the used term for which is ethos of science is of special interest for scientific ethics. Robert Merton's concept determined ethic standards serving for approval and defense of specific scientific values, including unselfish search and defense of truth. Social norms codified in scientific ethos by R. Merton into so-called CODUS are presented by four basic principles - Universalism, Communism, Disinterestedness and the Organized Skepticism.

The article also touches the aspects of the scientific responsibility of the researcher. Problems of scientific morality are especially acute for scientists working in the applied research fields, such as gene engineering, biotechnologies, biomedical and gene research of the human etc. As a result of scientific discoveries and the experiments the new "products" of researchers' activities are created, which consequences are sometimes irreversible not only for the whole mankind but for the science itself. Reinforcement of the accountability of scientists towards the society is also associated with social changes in science itself. Today, scientific and technological revolution changes the orientation of science, shifting it towards learning of social nature of the human. It is important for the scientific community to recognize the professional responsibility not only for the application of obtained results of the activities but for social consequences of it. A special attention should also be drawn to the improvement of monitoring of the activities of modern scientists and the scientific community in total by the public.
\end{abstract}

Keywords: scientific ethics, professional ethics, moral and social aspects of scientist's responsibility, ethical regulation, scientific ethos

\section{INTRODUCTION}

The importance of science in the modern society increases every year. The development of new technologies has increasingly serious and various impact on social life; the number of persons involved in scientific research increases, therefore reducing the interval of time between research activities and their practical application. Science turns

* Статья подготовлена на средства НИР № 101403-0-000, тема «Научно-технический прогресс и этическая парадигма в XXI в.» 
into production force and there will be a greater degree of scientists' responsibility towards the society and the mankind. Thus, we can look at the science as an object of moral estimation, and the research and results of scientific knowledge should be subject to ethical regulation of scientific activities.

\section{THE NOTION OF SCIENCE ETHICS}

In the 1980s problems of moral aspects of science and knowledge are actualized. When discussing the problem of interaction between science and moral, such basic aspects are identified as "ethical problems related to the role of science in the modern society, with social and moral responsibility of the scientist for scientific and engineering progress, for the application of scientific knowledge; ethical aspects of scientist's attitude to his/her labor; moral problems attributed to scientific creativity itself; the problem of ethical partnership within the research team; requirements applied to scientist's personality and behavior [1. P. 3].

It is noted that the ethical problem of science emerges where two forms of responsibility exist: internal and external one. That's why two visions of relationship between science and the ethics are present. On the one hand, we identify human activities, not the theories as subjects of moral assessment; from this point, science remains ethically neutral. From the other hand, science is a human labor, the result of his/her aspiration based on spiritual values and therefore it should be assessable. One should remember though, that "scientific knowledge is built up and evaluated on the basis of the whole body of methodological normatives...however, the knowledge cannot be limited by plain adherence to these norms. It always represents moving beyond barriers of previously defined knowledge and therefore it is a creativity requiring hard efforts of the imagination [2. P. 140].

To denote maximally wide circle of philosophical, methodology and sociological problems reflecting various aspects of correlation between science, moral and ethics, we usually use the term "Science ethics" [3. P. 71]. Creation of science ethics as a new trend in scientific philosophy and sociology dated to the late 1960s and the early 1970 [see 4].

We can also consider scientific ethics as the area of philosophical reflection regarding to moral aspects of scientific activities, including both relationships within scientific community and those between science/scientific community and the society in general [5. P. 701]. That's why the basic directions in scientific ethics which can be pointed out in this respect are those:

- external scientific ethics is studying of ethical problems resulting from the interaction between the society and science (see "social responsibility of the scientist" chapter);

— internal scientific ethics is a special section of scientific ethics which implements professional responsibility within scientific community.

Implementing principles of internal scientific ethics, the scientific community performs the following basic tasks:

1. Study of reality, search for new knowledge and its systematization.

2. Preservation and transfer of knowledge, popularization of science and scientific approach to understanding of the realities of life. 
3. Finding out new ways to increase the efficiency of human activities.

4. Training of scientists.

5. Protection of autonomy of science.

6. Supporting the positive attitude of the society towards science.

7. Estimation of scientific achievements and determination of status of its members depending on their contribution to scholarship.

8. Regulatory control of behavior of men of science, including ethic control.

9. Contribution to resolving societal problems and humanization of the society.

Thus, we can say that the scientific community is a professional association of men of science occupied with the accumulation, preservation and transfer of knowledge, protection of autonomous scientific activities, support of positive attitude of the society towards science, remuneration or punishment of scientists (assessment of individual scientific activities), review for compliance with the ethical code [6].

S. Lebedev, the scientist, completes the definition of scientific ethics, drawing attention to moral regulation of scientists' behavior. According to the author, scientific ethics is an "aggregation of moral norms, regulating scientists' behavior against: 1) scientific knowledge (cognitive freedom and responsibility); 2) each other (communicative freedom and responsibility); 3) society and the state (social freedom and responsibility); 4) itself (existential freedom and responsibility). The first type of moral attitude is due to creative, constructive nature of scientific research and relates to scientist's cognitive accountability for decision-making (responsibility towards the Truth). The second type of moral attitude is known as "ethos of science". The third type of ethic behavior of scientists is determined by the degree of their responsibility for development and application of science towards society and the state. The fourth type of ethical behavior of scientists is determined by the sense of their personal mission as scientists" [7. P. 312-313].

Thus, scientific ethics is a joint search for mindful solutions, in which both scientists and the society take part. The main issue of scientific ethics is a problem of correlation between scientific knowledge and value-based way of thinking. Goals and values in science have not always been understood as equal ones, for ages. For example, if during Modern era reaching to the truth was the primary goal of science, i.e. the truth itself was an important thing, another idea exists now, according to which the science primarily exists for the human, for resolving problems and goals of the mankind.

As noted, science ethics include scientists' professional ethics. But scientists' ethics are more finite constructs then scientific ones since they cover relational aspects of moral in science, those the scientists refer to [3. P. 71]. As a rule, the profession of the scientist is generally regarded to "free" professions, where the professional duty means much more than the wealth.

The problem of responsibility of scientists is closely linked to the issues of personal freedom and moral choice. That's why the specifics of moral responsibility are that it characterizes the attitude of the person towards the society, to his/her social and professional group from the point of view of his/her implementation of certain moral rules [7. P. 133]. 
Currently, basic rules of scientists' professional ethics are drawn up which can be separated into three groups. The first group is represented by common human moral standards adopted for the specifics of scientific activities (a ban on plagiarism, arbitrary distortion of results of scientific research, researcher's objectivity). The second group would comprise ethical standards which serve for approval and protection of sciencespecific values (selfless search for truth and its protection). The third group would comprise moral principles regarding to relations between science / the scientist and the society) [8. P.132-133].

\section{SCIENTIFIC ETHOS}

In addition to the issues of moral responsibility of scientists for results of scientific activities, of special interest for scientific ethics is an issue relating to the problem of moral assessment of cognitive activities per se.

To denote this problem in ethics of science uses the term "scientific ethos", introduced by Robert Merton. In the norms of scientific ethics are embodied both universal moral requirements and prohibitions. Also, ethical norms serve for the establishment and protection of specific values of science, including unselfish search, and upholding the truth. R. Merton gives a description of scientific ethos in the article "Normative structure of science" [9. P. 267-278]. In his opinion, scientific ethos is the set of norms that is reproduced in science and inherent in every professional in it, where science is the search for truth and rational critical discussion.

According to Boris Yudin, the researcher, Merton's normative concept of scientific ethos was used to characterize moral aspects of relationship between scientists within the scientific community. Each scientist is trying to get ahead of his/her colleagues in obtaining new scientific knowledge, to provide its acknowledgement by the scientific community, to maximize the share of material support of the research attributable to $\mathrm{him} / \mathrm{her}$ as well as recognition by the colleagues. And the common interest in maintaining the credibility of science and its reproduction in the society stimulate cooperation between scientists, which is a pre-requisite for formation and existence of scientific community [10. P. 593].

In 1942 R. Merton made an attempt to codify social standards of science. Scientific ethos is therefore created by four varieties of institutional imperatives - universalism, communalism, disinterestedness and the organized skepticism. Standards formed by Merton are usually recorded as an acronym, CUDOS, by first letters of each [11. P.9]:

1) $\mathrm{C}$ - Communism (communalism) - the result of the research is a public property and should be available for everyone;

2) U - Universalism: to be guided by common standards of reasonableness and argumentativeness. The estimation of any scientific idea or the hypothesis must depend only on its content and compliance with technical standards of scientific activities, not on author's social characteristics, e.g. his/her scientific reputation or belonging to certain scientific school.

3) D - Disinterestedness: researchers shall be emotionally disassociated with their study areas and run their search for truth without any prejudices. Above that, research results shall not be influenced by extra scientific interests (religious, politics, economics or personal). 
4) OS - Organized Skepticism: researchers shall be critical not only in aspects relevant to the work of others but to their own work.

The abovementioned ethos standards are obligatory, as they are not only effective but feasible, in Merton's view. Scientists see the system of standards as a guideline, the human factor, as any violation of ethic norms puts general functioning of science at threat. There are actual issues in modern science regarding not only to ethical standards of cooperation within the scientific community but to correlation between science/the scientist and the society, i.e. the problem of social responsibility of the scientist.

\section{SOCIAL RESPONSIBILITY OF THE SCIENTIST}

As noted above, social responsibility of scientists is being realized in relationship between science and the society. Thus, it can be characterized, first of all, as an external (social) ethics of science.

Strengthening of the responsibility towards the society is also related to change in social orientation of science. orientation of science The focus on development of technical means and the wealth in the context of scientific and technical revolution constantly gives way to focusing on a human, on study of his/her biological and social nature and living environment. Scientific concepts increasingly reflect not only the object of cognition but the cognizing subject and relations between them. Social and personal moments are actively involved into a process of getting scientific knowledge which leads to increase of degree of researcher's responsibility for technical application of obtained knowledge and social consequences of its application. Increasing humanization of science poses new ethical challenges to scientists, relating to possibility and feasibility of experimentation on human beings, its character and goals, the benefits it can bring to the mankind [12. P.41].

The understanding of that the search for truth is good in itself has changed. According to I. Frolov and B. Yudin, known Russian scientists, "not only consequences of practical application of scientific achievements, its "after effect", but also research processes themselves, i.e. research topics or failing to continue the research of certain problems, the character of designing and running the experiments etc. are becoming the objects of responsibility" [13. P. 160]. And then separate scientific disciplines, research groups and the researcher himself, not science itself, becomes the subject of the responsibility.

The responsibility of the scientist is directly linked with the issue of freedom in studies and scientific research - i.e. the responsibility is the downside of its scientific creativity. On the one hand, it is hard to imagine the responsibility without freedom; on the other hand, freedom without the responsibility turns into anarchy [14. P.34].

Among fields of scientific knowledge, where issues of social responsibility of the scientist and moral and ethics estimation of his/her activities are keenly debated, a special place is occupied by gene engineering, bio technologies, biomedical and genetic studies of humans.

The problem of moral responsibility became especially critical in 1975, when leading scalars of the world voluntarily signed the moratorium, thereby suspended certain 
life-threatening research [15. P. 152]. This is an example of that the social responsibility is inseparable part of scientific activities. Science study should include determination of ethical norms and standards which can be applied to regulate scientists' activities. Regulation of behavior of global scientific community will, in turn, require the implementation of international code of scientific ethics [2. P. 150 - 159]. Today Committee on Publication Ethics (COPE) has taken this responsibility in the field of publication ethics. COPE has written codes for scientists and editors of scientific journals, revisiting and developing the rules as the answer to new challenges to world scientific ethics [16].

Ethical problems emerging in modern science cannot be solved only through logic and ethics of cognition itself. It "requires their alignment with more widely understood social goals of cognition and humanistic ideals, with ethic valuables of the society as a whole" [13. P. 166-167]. Only that will enable us to find such resolution of vital problems which will meet the needs of progress and serve for the common good of the mankind.

\section{CONCLUSION}

Rapid development of science is increasingly raising questions among the mankind with regards to its future existence. The problem of not only moral but social responsibility of scientists for results of their discoveries is becoming urgent. The society itself also faces the special challenge, as it will probably have to run more strict humanitarian control of science. Ethical regulation of science and the appearance of high-level ethical culture is therefore the important pre-condition of development of science aimed at assurance of quality of its morality.

(C) Мухаметжанова В.С., 2018

\section{REFERENCES}

[1] Mishatkina TV, Jaskevich JaS, Vjazovkin VS. Ethics of science. Mishatkinoiy TV and Vjazovkina VS editors. Respubl. Institute of higher education. Minsk; 2002: 58. (In Russ).

[2] Frolov IT, Judin BG. Ethics of science: problems and discussions. Moscow: Politizdat; 1986: 140, P. 150-159. (In Russ).

[3] Ponosov FN. Modern philosophical problems of engineering and technical Sciences. Ponosov FN editor. Izhevsk: FGBOU VPO Izhevskaja GSHA; 2013:71. (In Russ).

[4] Lazar MG. Ethics of science as a new scientific direction of sociology of science. Journal of sociology and social anthropology. Saint-Petersburg: 2001;(3). (In Russ).

[5] Philosophical dictionary. 7th ed. Moscow: Respublika; 2001. P. 719.

[6] Digital library of Institute of philosophy RAS. Available at https:/iphlib.ru/greenstone3/library. Accessed: May 17, 2018.

[7] Lebedev SA. Philosophy of science: dictionary of main terms. M.: Akademicheskii Proekt; 2004. 312-313, 133. (Ser. «Gaudeamus»). (In Russ).

[8] Tsvyk VA. Professional ethics: foundations of a General theory. Tsvyk VA editor. Moscow: RUDN; 2012:32-133. (In Russ).

[9] Merton RK. The sociology of science: Theoretical and empirical investigations. Ed. and with an intro by Storer NW. Chicago and London: The University of Chicago Press; 1973. P. 267-278. 
[10] Judin BG. Ethics of science. In: Ethics: encyclopedic dictionary. (ed.) Apresyan RG, Gusejnov AA. Moscow; 2001: 593. (In Russ).

[11] Demina NV. The concept of the ethos of science: Merton and others in search of social geometry norms. Sociological journal. 2005; (4):9. (In Russ).

[12] Kochergin AN. Scientific creativity: problems of social responsibility and stimulation. Scientific Bulletin MGTU GA. 2010; (155):41. (In Russ).

[13] Frolov IT, Judin BG. Ethics of science: problems and discussions. Moscow: Politizdat; 1986: 160, 166-167. (In Russ).

[14] Gabdulova NN. Ethical problems of science. Proceedings of the Pskov Polytechnic Institute. 2008; (12.1):34. (In Russ).

[15] Bogatov VV. Ethics in scientific activity. Bulletin DVO RAN. 2008; (1):152. (In Russ).

[16] Tsvyk VA, Savvina OV. Publication ethics in the context of scientific ethics // Foster J.A., Lutton E., Miller J., Ryan C., Tettamanzi A.G., editors. Genetic programming. EuroGP 2002: Proceedings of the 3d International Multidisciplinary Scientific Conference on Social science and Arts SGEM; 2016 Aug 22—31; Albena. Bulgaria: Stef92 Technology; 2002. P. 791—797.

DOI: 10.22363/2313-2302-2018-22-3-301-309

\title{
ЭТИКА НАУКИ И ОТВЕТСТВЕННОСТЬ УЧЕНОГО
}

\author{
B.C. Мухаметжанова \\ Российский университет дружбы народов \\ ул. Миклухо-Маклая, 6, Москва, Россия, 117198
}

В статье рассматривается понятие этики науки, а также вопрос ответственности ученых в современном обществе. Автором раскрываются такие ключевые понятия, как этика науки, этос науки, определяется профессиональная и социальная ответственность ученого.

Бурное развитие научно-технического прогресса обусловило появление новых проблем и моральных ситуаций, связанных с этикой. Особый интерес для общества сегодня представляет проблема ответственности ученого за результаты его деятельности, за полноценную выработку научного «продукта».

В своей статье автор разделяет понятие ответственности на два вида - внешнюю и внутреннюю. Внешняя ответственность реализуется во взаимоотношениях науки и общества, и поэтому ее принято называть социальной. Внутренняя же представлена профессиональной ответственностью ученого в пределах научного сообщества. Как отмечает автор, проблема ответственности ученых тесна связана с вопросами свободы личности и морального выбора. В статье определяются основные нормы профессиональной этики ученого, среди которых запрет на плагиат, искажение результатов научных исследований, бескорыстный поиск и отстаивание истины, проблема свободы научного поиска и социальной ответственности ученого и т.д.

Особый интерес для этики науки представляет проблема моральной оценки собственно познавательной деятельности ученого, для обозначения которой используют термин «этос науки». Концепция Р. Мертона определила этические нормы, которые служат для утверждения и защиты специфических ценностей науки, в числе которых и бескорыстный поиск, и отстаивание истины. Социальные нормы, кодифицированные Р. Мертоном в этосе науки в так называемый CODUS, представлены четырьмя основными принципами - универсализмом (Universalism), коммунизмом (Communism), внезаинтересованностью или бескорыстностью (Disinterestedness), организованным скептицизмом (Organized Skepticism). 
В статье также говорится и о социальной ответственности ученого. Особенно остро проблемы нравственности науки стоят для ученых в прикладных областях: генная инженерия, биотехнология, биомедицинские и генетические исследования человека и т.д. В результате научных открытий и экспериментов создаются новые «продукты» деятельности ученых, порой последствия которых могут носить необратимые процессы не только для всего человечества, но и для самой науки. Также усиление ответственности ученых перед обществом связаны и с социальными изменениями самой науки. Сегодня, в условиях научно-технической революции, меняется ориентация науки, она смещается в сторону познания социальной природы человека. Научному сообществу важно осознавать не только профессиональную ответственность за применение полученных результатов деятельности, но и социальные последствия их применения. А также особое внимание стоит обратить на повышение гуманитарного контроля со стороны общественности за деятельностью современных ученых и научного сообщества в целом.

Ключевые слова: этика науки, профессиональная этика, моральная, социальная ответственность ученого, этическое регулирование, этос науки

\section{ЛИТЕРАТУРА}

[1] Мишаткина Т.В., Яскевич Я.С., Вязовкин В.С. Этика науки / Республ. ин-т высшей школы / под общ. ред. Т.В. Мишаткиной и В.С. Вязовкина. Минск, 2002. С. 58.

[2] Фролов И.Т., Юдин Б.Г. Этика науки: Проблемы и дискуссии. М.: Политиздат, 1986. C. $140,150-159$.

[3] Поносов Ф.Н. Современные философские проблемы техники и технических наук. Ижевск: ФГБОУ ВПО Ижевская ГСХА, 2013. С. 71.

[4] Лазар М.Г. Этика науки как новое научное направление социологии науки // Журнал социологии и социальной антропологии. СПб., 2001. № 3.

[5] Философский словарь / под ред. И.Т. Фролова. 7-е изд., перераб и доп. М.: Республика, 2001. C. 719.

[6] Электронная библиотека Института философии РАН [Электронный pecypc] https://iphlib.ru/ greenstone3/library (дата обращения 17.05.2018).

[7] Лебедев С.А. Философия науки: словарь основных терминов. М.: Академический Проект, 2004. C. 312-313, 133. (Cep. «Gaudeamus»).

[8] Цвык В.А. Профессиональная этика: основы общей теории морали. М.: РУДН, 2012. C. $132-133$.

[9] Merton R.K. The sociology of science: Theoretical and empirical investigations / Ed. and with an intro by N.W. Storer. Chicago and London: The University of Chicago Press, 1973. P. 267-278.

[10] Юдин Б.Г. Этика науки // Этика: Энциклопедический словарь / под ред. Р.Г. Апресяна, А.А. Гусейнова. М., 2001. С. 593.

[11] Демина Н.В. Концепция этоса науки: Мертон и другие в поисках социальной геометрии норм // Социологический журнал. 2005. № 4. С. 9.

[12] Кочергин A.Н. Научное творчество: проблемы социальной ответственности и стимулирования // Научный вестник МГТУ ГА. 2010. № 155. С. 41.

[13] Фролов И.Т., Юдин Б.Г. Этика науки: Проблемы и дискуссии. М.: Политиздат, 1986. C. $160,166-167$.

[14] Габдулова Н.Н. Этические проблемы науки // Труды псковского политехнического института. 2008. № 12.1. С. 34.

[15] Богатов В.В. Этика в научной деятельности // Вестник ДВО РАН. 2008. № 1. С. 152.

[16] Tsvyk V.A., Savvina O.V. Publication ethics in the context of scientific ethics // Foster J.A., Lutton E., Miller J., Ryan C., Tettamanzi A.G., editors. Genetic programming. EuroGP 2002: Proceedings of the 3d International Multidisciplinary Scientific Conference on Social science and Arts SGEM; 2016 Aug 22-31; Albena. Bulgaria: Stef92 Technology; 2002. P. 791—797. 
Для цитирования: Mukhametzhanova V.S. Ethics of science and responsibility of scientist // Вестник Российского университета дружбы народов. Серия: Философия. 2018. Т. 22. № 3. C. 301-309. doi: 10.22363/2313-2302-2018-22-3-301-309.

For citation: Mukhametzhanova V.S. Ethics of science and responsibility of scientist. RUDN Journal of Philosophy. 2018; 22 (3):301-309. doi: 10.22363/2313-2302-2018-22-3-301-309.

\section{Сведения об авторе:}

Мухаметжанова Винера Саяровна - кандидат социологических наук, доцент кафедры этики факультета гуманитарных и социальных наук Российского университета дружбы народов. (e-mail: mukhametzhanova_vs@rudn.university) 